Marquette University

e-Publications@Marquette

Philosophy Faculty Research and Publications

Philosophy, Department of

$1-1-2004$

\title{
Resentment and Assurance
}

Margaret Urban Walker

Marquette University, margaret.walker@marquette.edu

Published version. "Resentment and Assurance" in Setting the Moral Compass: Essays by Women Philosophers. Ed. Cheshire Calhoun. Oxford; New York: Oxford University Press, 2004: 145-160. Publisher link . (C) 2004 Oxford University Press. Used with permission.

Margaret Urban Walker was affiliated with Arizona State University at the time of publication. 


\title{
Resentment and Assurance
}

\author{
Margaret Urban Walker
}

Resentment is a kind of anger. It is widely agreed that resentment predicates some kind of wrong at others' hands and that it is in some way a defensive emotion in its operation or its manner of expression. The most widely cited contemporary account of resentment, Jean Hampton's, renders the anger, wrong, and need for defense in a particularly colorful way. ${ }^{1}$ Hampton's is an individualistic and agonistic account of resentment. Beings acutely aware of their "value and rank" are moved to anger by injuries to themselves that challenge their presumed standings, and they are mobilized in fearful defense of the self-esteem these standings underwrite. Hampton uses this agonistic picture to make resentment itself look somewhat shabby and misguided, a defensive reaction based on dubious views that one's own human worth can actually be diminished by others' actions.

An older account of resentment paints a more social and less self-referring picture of it. In his sermon "Upon Resentment," Joseph Butler describes “deliberate anger or resentment" in this way:

The natural object or occasion of settled resentment then being injury, as distinct from pain or loss; it is easy to see, that to prevent and to remedy such injury, and the miseries arising from it, is the end for which the passion was implanted in man. It is to be considered as a weapon, put into our hands by nature, against injury, injustice, and cruelty. ${ }^{2}$

Butler viewed deliberate resentment, when not groundless, extravagant or vengeful, as "one of the common bonds, by which society is held together; a fellowfeeling, which each individual has in behalf of the whole species." ${ }^{3}$ It is that by which "Men are plainly restrained from injuring their fellow-creatures by fear" when virtue would not suffice. ${ }^{4}$

$I$ argue that resentment is a versatile and economical emotion that serves the negotiation of shared lives pervaded by norms and the expectations to which they give rise. Shared life requires mutually recognized boundaries and fairly reliable 
expectations based on them. Responses that target violations and prompt violators to reconsider and to beware or those that signal the need for this sort of action are thus important, and resentment plays, I argue, this sort of role. ${ }^{5}$ Occasions of resentment are in fact many and more varied than either Hampton's or Butler's discussions would suggest. I claim that what best explains the extent and variety of possible occasions for resentment is that resentment responds to perceived threats to expectations based on norms that are presumed shared in or justly authoritative for common life. In some cases resentment also responds to experienced threats to one's standing to assert or insist upon those norms. Possibilities for resentment are many because the field across which intelligible resentments range is as broad as that of behavior to which norms are taken to apply. This range of behavior includes table manners and modes of dress and address, as well as styles of life and social interaction and matters of justice and basic decency among human beings. While resentment registers anger at threats to expectations underlain by norms, or to one's standing as a competent judge of operative norms, it targets others' intentional acts as the source of threat and tends to impugn their motives and attitudes. Resentment is an accusing anger, one that calls others to account, as P. F. Strawson argued in calling resentment a "reactive" attitude that attributes responsibility. ${ }^{6}$ But at the same time, as I explain below, resentment not only sends a message but also invites a response: it seeks assurance from offenders or from others that they can be (or be again) trusted to reaffirm and respect the boundaries that norms define, boundaries that offer protection against harm or affront, as well as the security of membership and reliable expectations in a community of shared normative judgment.

I see my account as being in the spirit of Butler's, endorsing his insight into the deeply social and expressive aspects of resentment. Butler's characterization of resentment as a "fellow feeling" is multiply apt. Resentment extends to injuries or exclusions of those one takes to be one's fellows, but it can also forge a sense of fellowship where it had not been felt before. In addition, it can be prompted by threat to one's sense of belonging with others in a community of judgment that shares standards. When Butler speaks of resentment as a "weapon" against injury, injustice, and cruelty, however, he not only draws the defended territory too narrowly but is also sanguine about our equal entitlements to bear and brandish these emotional "arms." And he is hasty in supposing that the effects of so doing are likely to be uniform or as intended. Attention to a fuller array of examples will help to show this.

It is Hampton's more widely known contemporary analysis, however, that I will examine first, using limitations in her account to draw out features of my own view. To be clear at the outset: I don't take Hampton (or Butler) to be attempting an account of necessary and sufficient conditions of resentment, nor do I attempt one. I take it that Hampton's account, as does my own, aims at a "normal form" characterization of a syndrome of feelings and expressions that in certain kinds of contexts is likely to be identified as resentment. I believe the grammar of emotion terms is somewhat rough and ready. This means that not much is settled simply by butting intuitions about individual cases against one another. Our emotion 
vocabularies are not that neatly regimented, and whether someone is willing to call one scenario or another a case of resentment is not so significant as the reasons that we are inclined to describe cases in that way or in some other way. Descriptively, the point is to achieve a characterization that covers the widest class of common cases and, better still, that sheds light on why contested examples cause disagreement. Explanatorily, a plausible account should make sense of the roles that the experience and expression of the emotion play in our shared lives. The view I develop here is meant to address those descriptive and explanatory challenges. The question of when resentment is justified and deserves to receive the satisfaction it seeks is not my topic here.

\section{Getting Resentment in Broader View}

For Hampton, resentment "is an emotion whose object is the defiant reaffirmation of one's rank and value in the face of treatment calling them into question in one's own mind." In her view, resentment serves at once as a protest and defense. ${ }^{8}$ The occasion of resentment for Hampton is "being wronged," which is not only being damaged or hurt but also being so in a way that "insults" or is "disrespectful of" one's worth, however that is conceived (e.g., as relative or absolute or fixed or variable). " "Resentment," she says, "is an emotion which reflects their judgment that the harmful treatment they experienced should not have been intentionally inflicted on them by their assailants insofar as it is not appropriate given their value and rank." ${ }^{10} \mathrm{~A}$ resentful victim of wrongdoing is thus angry-more particularly "defiant" or "battling" against the lower standing imputed to him or her by the culpably disrespectful harming. ${ }^{.1}$ But at the heart of resentment, Hampton sees something defensive in another sense; she believes its angry defiance reveals a fear. It is feared that the offender is right to think that the victim's worth is as implied in the insulting treatment or that it is permissible to lower the victim in rank by means of such an action ("putting her in her place"). ${ }^{12}$ So resentment combines anger and fear.

Hampton draws a distinction between resentment and indignation, claiming that indignation is an impersonal anger at a challenge to "someone's value," which threatens a standard of value, whereas resentment is personal anger and defends oneself "against the action's attack on one's self-esteem" and is "normally an emotion experienced only by the one who has been harmed. ${ }^{13}$ One's selfesteem is threatened by the possibility that the action has revealed one is or has now been made lower in rank or value than one was or had assumed.

So, for her, the occasion of resentment is being culpably wronged. The constitutive belief in resentment is that one's deserved or true rank and value have been impugned or imperiled. The feeling of resentment embodies anger at insult and its implications and fear that one's status is lowered or one's diminished status is revealed. The object or aim of resentment is to defend and protect self-esteem.

Hampton's view of resentment is narrow in several ways. Consider her limitation of resentment to reactions in defense of oneself when it is oneself who is 
wronged. This seems implausibly restrictive, for we commonly enough speak of resentment at the way others are treated or looked at, nor must these others be ones with whom we have personal connections or prior identification. One can, looking on, resent a sales clerk's rude treatment of a shabbily dressed person, the condescension of a teacher to a girl in a physics class, or the self-congratulatory attitude of a wealthy political candidate who is discussing problems of "the poor" when these actions involve or refer to strangers or groups to which one does not belong. Furthermore, the distinction Hampton makes between supposedly impersonal indignation and allegedly personal resentment is unconvincing. Diners badly served their suppers or employees failing to receive their anticipated bonuses may be the very type of the indignant individual. So indignation is quite commonly a reaction to injuries to oneself taken very personally indeed, whereas resentment can just as well take the cause of others to heart. Resentment and indignation, in fact, may not be distinct emotions; in the modern but older usage of Butler (or Adam Smith), the two are not distinguished and the terms are used interchangeably, as when Butler spoke of resentment as "the indignation raised by cruelty and injustice." But even without settling the precise nature of the difference between indignation and resentment, I think there are enough examples to confute the alignment of resentment and indignation, respectively, with what is "personal" and "impersonal" or what concerns "self" and "other" for reasons I expand below. No doubt to resent something is to "take it personally," but the sense in which this is true remains to be spelled out.

Hampton wants to see resentment and indignation as distinct but parallel, with resentment as the personal version and indignation as the impersonal version of angry fear at wrongdoing. But this doesn't seem to work either, for straightforward cases of indignation don't seem to be marked by the fearfulness that Hampton, and not she alone, associates with resentment. The indignant person is characteristically the picture of confident or unreserved righteousness. For that matter, not all cases of resentment seem to involve fear. A gentleman who is spoiling for a fight may coolly brandish his resentment at an insult as a provocation to a contest-say, a duel-he has little fear of losing. A dominating husband may resent and expressly avow resentment of his wife's wage earning, confidently and correctly surmising that the fact of his resentment will cause her to quit her job.

Yet the term "resentment" seems tinged for many people with associations of someone cringing or sulking in gnawing and roiling anger that is tamped down or turned inward, as if out of fear. I have no doubt that Nietzsche's memorable creation of the image of ressentiment - a kind of seething, angry envy of the powerful by the powerless, who must nonetheless hang back in their despicable weakness - has had an impact, and not only on philosophers. But it is well to remember that Nietzsche is not talking about resentment in any commonplace sense. He coins a novel term of art to advance an imaginative scenario in which morality itself emerges as a kind of brilliant trick of the weak, who remain nonetheless despicable in their weakness. The fictional Nietzschian drama is propelled by what we would more usually describe as envy of the superiority of the strong. ${ }^{14}$ 
I return below to some ways in which resentment can be inflected by envy or fear, as also by disgust or bitterness, and to some reasons that resentment is apt to be differently inflected for those in positions of relative weakness. But the examples above of the insulted but confident gentleman or the successfully dominating but irritated husband, as well as a very broad array of cases of resentment at offense that I discuss shortly, suggest a different explanation of what prompts resentment. What is central to resentment on this explanation is a perceived threat, whether or not one has reason to fear what is threatened and whether or not one in fact does fear it. A threat suggests a prospect of damage to or loss of something valued, and people can get angry at the suggestion that someone is inclined to act in a way that might damage or get in the way of what they count on or deem important, even if they have no fear of heading off the threat. The sometimes in-turned or tamped quality of resentment in many cases may have more to do with the position the resenting one is in: one is not always in a position to give forthright expression to one's anger at a perceived threat. The nature of the display of this kind of anger is sensitive to the position-situational, emotional, social, and institutional-one is in to show how one feels or to anticipate a desired response to that display. ${ }^{15}$

Another questionable claim in Hampton's account is that resentment is a strategy aimed at defending self-esteem (or "self-respect," which she uses interchangeably in this context). This seems to require that a resenting person has some modicum of self-esteem to defend. She says that "the ability to feel resentment following a wrong-doing depends upon one's having enough sense of one's own worth to believe that the treatment is inappropriate and worthy of protest." Similarly, Jeffrie Murphy, her interlocutor in Forgiveness and Mercy, holds expressly that resentment defends one's self-respect and that proper self-respect is essentially tied to resentment, so that "a person who does not resent moral injuries done to him ... is almost necessarily a person lacking in self-respect." ${ }^{17}$ Yet there is a lot of everyday evidence that people need not hold themselves highly, indeed, not respect or esteem themselves at a basically decent level, to be great resenters. Self-abasing flatterers, cringing self-despisers, and miserable sellouts, or people beaten down or those consumed with self-hatred of their powerlessness, are quite capable of resentments, including resentment of others to whom they self-abasingly bow or of others who maintain dignity or integrity under circumstances similar to their own. Unless one wants to award the honorific "self-respect" to anyone who won't bridle at something, it seems resentment need not imply selfrespect in even a modestly positive sense. On the other hand, whereas resentment is possible and common for those who fail to respect themselves, those who enjoy robust self-respect may be magnanimous or respond with confidence or determination rather than resentment, even when they are themselves treated ill or are the object of neglect or undeserved indifference. Self-respect, then, is not obviously either necessary or sufficient for experiencing resentment when threatened or even when injured or affronted.

Finally, it is questionable to narrow the response of resentment to harmful and insulting treatment intentionally inflicted. This description calls up vivid im- 
ages of abusive or disrespectful treatment that would make one wince to observe, as well as to suffer. Cases like this surely merit resentment if any do. But this identification of occasions for resentment with damage and injury both pushes aside the pervasiveness of resentment in everyday life and tends, misleadingly, to moralize it. Resentment is often provoked by the good, generous, fair, or even simply decent treatment of others when the resentful one feels convinced that she would not have fared as well or perhaps remembers an instance in which she did not, or when she thinks that it is she and people like her, and not those others, who are entitled to the treatment or rewards in question. And there is also the familiar case of charged and evident resentment felt in response to those perceived as exceeding their places, prerogatives, and authority, those who are "uppity," "arrogant," or "too big for their britches." They seem to illustrate that it can be just as threatening to see some others claim respect and receive good or dignifying treatment as it is for oneself to be shown to the lower rung of the status ladder. More surprising, perhaps, is the extent to which resentment arises at the behavior of others that simply upsets established patterns and expectations.

\section{Resentment and Threat}

My objection to Hampton's view is not that she has not identified and explored insightfully the ways in which resentment results from perceived injuries that are insults to status (her "rank and value"). My objection is that she has ignored the broader field in which being demeaned by being treated below one's status constitutes one kind of occasion for resentment that can be placed within a more general account. Here I make a start on that.

In my view, resentment is best explained as a defensive response of anger (and in some but not all cases, fear or other negative feelings) to others' intentional actions perceived as violating boundaries defined by norms. Sometimes the violation is an actual injury, but even then it is not only the harm caused but also the sense of wrongfulness of the behavior causing the harm that is characteristic of resentment (in distinction to other kinds of anger, which may arise from frustration or thwarting that need not issue from another human agent or can be directed at human agents whose motives we need not impugn). The wrong is defined by some supposed rule or standard, a norm. The constitutive belief is: they should not have acted in that way. Strawson points out that the pain may be as unpleasant in a case in which someone treads on my hand accidentally as when one does so out of contempt, but it is the latter case that is ground for resentment because of "the very great importance we attach to the attitudes and intentions toward us of other human beings." ${ }^{18}$ But before we get so far as attitudes and intentions, notice how various are perceived wrongs to which resentment is a response.

Resentment is occasioned not only by harms and losses, as when one is assaulted, cheated, made to suffer, or forcibly relieved of one's goods, but also by cases in which some ride free or manipulatively profit in excess ways from roles, 
systems, or cooperative practices in which others comply without extra profit; call these exploitations. ${ }^{19}$ Resentment can also be provoked by someone's assuming a position or being treated as entitled to a status that disturbs a presumed status ordering; call these improprieties. If the disturbance makes the resenter's position or status lower or less valuable than it had been or than he or she believed it to be, we might call these demotions. Then there are cases in which one endures treatment beneath his or her proper status-slights. Finally, resentment is often enough prompted by rule breaking, norm violating, or simply behavior seen as "out of bounds," even without evident profit to the violator or harm or expense to others; call these offenses. These are things "not done" or "unacceptable." Harms, losses, exploitations, improprieties, demotions, and slights may be my own or others, and they may inspire resentment on my own or on others' behalf. Offenses may be apparently victimless social fouls.

The category of offenses is vast but significant not only for that reason. It also reveals something about what can occasion resentment and thus about what can be at issue in it. People seethe and prickle with resentment at those who laugh too loudly, speak too freely, fail to say "please" or "thank you," or utter other conventional formulas; at fashion fads, the piercing of body parts (now, other than ears), and weird haircuts; ${ }^{20}$ at the yelps of other people's children and at people's sitting closer on a bench or bus than they must; and the list goes on and on. One explanation of many of these "offending" occasions given by William Miller is the enormous social importance of "disattendability," explored so acutely by sociologist Erving Goffman, by which what is ordinary, routine, and normal generates "normative expectations" to which we hold people accountable, if only in the medium of untoward feelings like disgust, alarm, pity, contempt, embarrassment-and, of course, resentment. ${ }^{21}$ Cases of offense or affront are revealing, for what we see in them is not a harm or injury in the usual sense but an occurrence construed as a threat either to a norm or familiar pattern imbued with some prescriptive force by the perceiver.

In all cases of resentment, it seems we are angry because (we think) we or others are injured or because we are (we think justifiably) affronted by the actions of some who have gotten out of bounds. Someone has made free with what we thought were the rules, crossed boundaries we supposed intact, ignored claims we believed authoritative, or rendered idle or ridiculous our hope that things will go on in any of the many ways we believe they should. The sense of threat in resentment, as Strawson claimed, tends to go to the agent's apparent malice or indifference, when we suppose he or she might have shown the good will, attention, due care, respect, or understanding that would have led to proper behavior. In many cases, although perhaps not all, the proper will, care, or attitude is what we had expected to be shown; in all cases, we must think that it could have been. As Strawson noted, resentment is a feeling that impugns the agent and imputes responsibility, and so culpability, for some kind of wrong. There is threat both in a norm's being tested by overt noncompliance and in the presumption that the agent in getting out of bounds displays irresponsibility or worse. There can also be a threat to the resentful perceiver's sense of authority and competence as a 
judge of what "is done" or "goes" or is acceptable "among us" if one's resentment is not shared or its eliciting violation is not recognized by others.

In cases of direct injury and insult, one is not so likely to be wrong in thinking that something unacceptable has occurred. But the case of offenses is again not only revealing but instructive as well. For in the case of offenses, many a resented behavior is seen as "out of bounds" not only in the absence of any actual injury, and even when the behavior is in no apparent way "aimed" at the one who resents it, but also when ill intent by the agent is undetectable by reasonable observers. These are the cases in which as onlookers we feel inclined to say to someone wrought up with resentment, "What's it to you?" This question is exactly the right one, for it requests an interpretation that at least specifies the transgression (what is wrong here, which may not be obvious to others) if not the faulty attitude it may seem to embody. One common resentful response, however, is also apt: "Who do they think they are to ... ?" This goes to the heart of the matter of resentment. The offender is taken to be "thinking" that he or she is exempt from some requirement he or she must or ought to know applies. Resentment carries this implication of a faulty attitude on the actor's part.

This is a danger inherent in resentment. We may not have independent reasons to believe people bear us ill will or are indifferent or careless when we find that what they do threatens our sense of a prevailing order, but it is very easy, and it seems very common, to translate one's own sense of threat back into an attribution of fault or malice in the intentions of others. Resentment embodies a sense, or an implicit and presumptive imputation, of fault that can be difficult to dislodge, and one gripped by resentment may be far more disposed to find fault in others rather than to question whether one's own resentment might be misplaced or exaggerated. And it is also true that when people resent hearing "foreign" languages spoken, encountering people of racial or ethnic groups other than theirs in their neighborhood, or seeing evidence of gay and lesbian households, there is usually a prior belief that some kinds of people aren't to be trusted or accepted to begin with, and the fact that people like that are intruding where they don't belong is additional evidence of their inappropriate presumption or aggressiveness. Those already resented are likely to arouse yet more resentment for behaving as if they don't know - and shouldn't they? - that they aren't the kind who belong.

Whether it is correct or not in particular cases to infer that an agent's attitude is faulty, though, the central matter of resentment is an injury or affront that is threatening in disappointing expectations, or dimming or dashing hopes, for others' conduct that in some sense we think we had a "right" to. ${ }^{22}$ The best explanation of that "right," I claim, is the belief in an operative norm of some kind, although not necessarily a moral norm. The huge category of resented offenses alone suggests that resentment should not be "moralized." What threatens is the license taken by some with what others of us take to be the operating understandings, limits, or rules. In the case of injury or cruelty, for example, the sense of threat is urgent because actual harm is the result of an offender's failure to abide by or to be restrained by a norm, and more such harm might be forthcoming. Or if someone receives treatment inappropriate to his kind in a system carefully ar- 
ranged around appropriate responses to kinds of people, that rankles but also threatens those faithful to that system: where will this breakdown of order lead? This is as true when a murderer goes free on a technicality as when a member of a despised racial group is treated with respect.

The threat that prompts resentment, made fully explicit, is of license with impunity. The transgression announces a possibility that is at least annoying, often alarming, or even fearsome-a possibility that might persist unless something forecloses it. So the fact of the transgression puts in question, even threatens, whatever confidence, trust, assurance, or hope allowed one to be unconcerned about such injuries or affronts or unburdened by their unsettling implications. This is the sense in which we "take personally" what we resent. It is not that what we resent necessarily is an injury or insult to us ourselves or even an affront aimed specifically at us. Rather transgressions against boundaries cause us concern when they announce the possibility of something we might have to reckon with-a factor that throws us uncomfortably out of our normative expectations, moral and otherwise, or undermines our ability to assert with confidence what and where certain social, moral, or interpersonal boundaries lie. In that threat lies a potential for fear, as for other negative feelings, that can flavor resentment or compound it.

Resentment is itself a "weapon" (using Butler's image) - an unpleasant, accusing, and potentially threatening response when expressed overtly at the offender. When apparent to others, it is also, to continue the image, a kind of "call to arms." Where there is opportunity and ability to get transgressors back within bounds, to impose some corrective action on them, or at the very least to summon support from others for a clear repudiation of what transgressors have done, resentment may be relieved as the threat is diminished. It is something at least if the rules and boundaries are reiterated, even if the individual offenders go unpunished and are no longer trustworthy. It is better, of course, if we can be assured that punitive treatment of transgressors serves as an informative and possibly deterring example to others. It is best if those who have broken the rules can actually be brought to reaffirm their subscription to them. Yet often the opportunity or ability to correct offenders or to inflict reprisals on them is uncertain or unavailable. Worse, sometimes repudiation is not forthcoming from any others, from enough others, or from others with authority. Then the threat of license with impunity is fulfilled. In such cases, there is a basis for resentment at a transgression to turn disgusted, bitter, envious, shamed, or fearful.

Resentment can be disgusted, for example, in a case in which one has ceased to be surprised at certain goings on and has given up any thought that one can forestall their occurrence or defend against them. ${ }^{23}$ Consider the situation of a lone female office clerk in a welding shop who has failed to become inured to pinup calendars and continuing sexual insults and challenges. If she no longer rises to the bait emotionally she might still disapprove of her coworkers' conduct. What is missing if she ceases to resent it? She might without any longer experiencing resentment continue to disapprove of her coworkers' conduct and continue to believe that the norms that define it as rude, insulting, and hostile are valid and that her coworkers know very well that what they do is at least some of these 
things. But if she still resents these goings-on-if she still gets angry about the wrong these goings-on inflict on her, or on women in general, and does not merely shrug and think, "It's not supposed to be that way, but who can do anything about it?"-her resentment reveals that she continues, quite precisely, to "take it personally." The wrongfulness of their behavior gets a grip on her and moves her emotionally and motivationally in the direction of her own hostile display - a kind of accusing anger that puts her in the expressive position of rebuking them. Her resentment is that rebuke.

But even if she feels resentment, she might not show it. Even though resentment disposes her to show her anger in overt and confrontationally angry displays, actually showing anger in her situation may not be a sane or safe option. She may know that this leads to escalation or attracts reprisals. She may then find that her anger takes the form of a withdrawal or recoil in disgust from the situation. She might begin to experience her coworkers to some extent as a kind of noxious substance in the environment, rather than as fully fellow agents who can and should be confronted with their knowing misbehavior; she may also experience self-disgust at her own sense of powerlessness or her failure to recruit others to negative judgment or rectifying action. Her resentment may mingle with disgust, or disgust may simply replace it. Her resentment itself may move her in directions that in turn provoke other feelings that modify the expression and course of the resentment or perhaps cause resentment to give way to other, less stressful, costly, or defensive feelings, where active resistance isn't going anywhere. ${ }^{24}$

Bitter resentment might similarly involve scenarios in which one cannot stop blaming some others for failing to supply at least a community of confirming judgment, if not actual protection, from injuries or affronts that one cannot or will not "learn to accept." Sometimes people are supposed to accept the treatment they protest, and sometimes they are supposed to accept the futility of their protesting that treatment. People are called "bitter" who can't seem to stop complaining, those whom others see as stuck in an accusation that is not (in the eye of the beholder) going to change anything. Those who find themselves increasingly isolated, justly or not, in their accusation may find that resentment acquires a brittle quality, less an accusing display than a kind of choked protest that already anticipates it will be ignored or refused by others. ${ }^{25}$

Resentment may mingle with envy when one repudiates what others do but at the same time wishes one had the power, nerve, or panache to get away oneself with what they do. This is the variation on resentment that Nietzsche's ressentiment captures and inflates to mythic proportions. But although envious resentment (or resentful envy) is real, it would be a mistake to think that all resentment involves envy. That would be to deny that anyone ever burns with anger at wrongdoing without actually, perhaps secretly or unconsciously, wishing that one could get away with what wrongdoers do or could themselves have the attributes that make wrongdoers capable of violating norms. Resentment might invite shame when one wants to be able to express one's anger in a way that rebukes someone's behavior but is too timid or prudent or ingratiating to do so. The shame accompanying resentment is more poignant, though, when one is invisible or so negligible 
in others' eyes that the protest one's resentment reveals is beneath the notice or concern of others. It is easy to see how shamed resentment could breed envy: the miserably treated servant might rather be the tyrannical master, if those are the only positions available in certain social worlds. But it would be dangerous to assume that those oppressed or slighted necessarily yearn to turn the tables; often, they want to overturn those particular tables and level the ground for future relations.

On my account of resentment, when people cease to resent things they once did it reveals some kind of resignation, a kind of "normative surrender." This might involve ceasing to believe that a norm is valid, losing expectations that a valid norm will be honored and letting go of a personal stake in that norm, or losing conviction that one is in a position to assert shared norms, or at least certain ones, with any effect. But when people continue to resent certain behavior even as they recognize that their normative investment is neither shared nor enforceable (at least locally), the residual resentment preserves and expresses a personal "normative stake," an insistence on the validity and importance of a norm, a repudiation of the prevailing situation of dereliction or insouciance, and so a continuing normative protest of what exists in favor of what should be. They continue to take it personally.

Resentment can also be fearful. The association of resentment with fear is common, as noted above, and with reason. Fear comes in with resentment especially in cases of (standing or passing) vulnerability and inadequate or unreliable defense-that is, when one does not expect one's resentment to constitute an effective accusing and restraining signal. Worse, in some weak positions, one might fear that one has invited additional harm or threat for having shown resentment-a kind of anger-in response to the original harm or threat. In any case, fearful (and perhaps disgusted or bitter) resentment can involve second-order fear. It is bad to be injured or affronted, and so as a result to be under threat of, even in fear of, further injury or affront because what protected you from it is destroyed or in doubt. It is worse to see no way to reestablish security, for now you are afraid that you are going to have to be afraid, to live in fear, without assurance or protection of a community of shared boundaries that one's fellows are willing to assert and enforce. Second-order fear is understandable in continuing situations of weakness, including situations of continuing subordination by role or status. Members of oppressed, stigmatized, or despised groups are continuously vulnerable in such ways, across many social situations and encounters. Second-order fear might be one of the conditions in which resentment assumes a "roiling" or "gnawing" quality, an accusing anger that can't, because it must not, get "out" expressively.

Resentment that is fearful feeds on exposure to injury in virtue of one's demonstrated vulnerability or exposure to affront in view of the apparently negligible importance or authority of one's expectations or hopes. Yet I have argued that even resentment that is not fearful turns on a sense of threat. This suggests an explanation of why some injuries to others can excite resentment whether or not one "identifies" with those injured or offended. Indeed, it explains why the perception of another's being injured or affronted can sometimes prompt identification with him or her that was not there to begin with. In some cases the breach 
of bounds that reveals the vulnerability of others causes us to recognize that we, too, are exposed and that we have something in common with them. If what threatens us is license with impunity, then those upon whom objectionable action is visited are not the only ones threatened, for the offender who will go beyond bounds could be a future menace or a dangerous example to others. In the case of victimless offense to presumed standards, the authority of the standards we rely on is jeopardized, and our confidence in proceeding on the basis of these standards, or even a hope that these standards will be respected, is undermined. In other cases we may feel that our group membership is threatened, either because we are no longer sure that our community is one whose operative standards we can accept or respect or because we feel defeated in our attempt to grasp and apply standards that are operative. Is a community that harbors or tolerates this sort of thing really one I can call mine? Or is my competence as a judge or the authority of the standards I assume are common put in question here? Am I "out of it"? There are significant resentments of alienation and marginality, in which one's protest simply places one outside serious consideration: one is an old fogie, a wacko, a malcontent, a whiner.

\section{Resentment as Moral Address}

To come back to the central point, whether or not resentment is further driven or infused by other feelings, it is a kind of accusing anger at something done. The anger is directed at the doer of what is out of bounds, with the implication that the doer knows, or ought to know, better. Does the anger of resentment have an aim? If expressions of resentment tend to play as protests, rebukes, or demands ("I resent that" or "How dare you/he/she?" or "There ought to be a law"), what satisfaction does resentment seek? To ask this question is to assume that some emotional responses have not only an etiology in certain perceptions but also an expressive point or communicative direction. Resentment seems to be one such emotion. Hampton claims that in resentment the victim "would have it" that rank and value are not lower or lowered because that is on her account what is threatened. Butler seems to think that resentment seeks or threatens the punishment of the offending party in order "to remedy or prevent harm. ${ }^{26}$ On my account, what resentment calls out for is assurance of protection, defense, or membership under norms brought in question by the exciting injury or affront. What can assuage resentment of actual injury is renewed trust or hopefulness that people, including oneself, will be defended or protected. And what reassures us in the face of affront is confirmation that our sense of boundaries is shared; it is those who offend who are up for negative appraisal, rebuke, or exclusion, not we who will be ignored, ridiculed, or silenced. Now, to whom are resentment's rebukes or demands expressed?

I have already mentioned Strawson's famous article on resentment and other reactive attitudes. Strawson considered resentment a "reactive attitude," and these, it has been pointed out, are a kind of moral address: they are expressive not only because they reveal something going on in the one who experiences them but 
also because they are a kind of communicative display that invites a kind of response. ${ }^{27}$ They address those at whom they are directed and often others, bidding them to recognize the existence or the possibility of a kind of relationship. In the case of resentment, the appeal or invitation for assurance of protection, defense, or membership might sometimes be addressed to the offender: The angry display "sends a message" to the offender about the unacceptability of the offender's behavior. This sort of case is what Butler had in mind, and it seems to be the response now characteristically read as indignation, overt rebuking anger. But the assumption that one's accusing and reproving anger and the possible reprisal it portends will be effective supposes one is in a position to accuse, reprove, and threaten the transgressor. Many of us in many situations are not in this position. When resentment is fearful because of vulnerability, fear would be the wrong message to address to an offender when the offense displays ill will or bold indifference (rather than neglect), and so when the victim's fearful vulnerability might constitute exactly the wrong sort of invitation, that is, an invitation to further aggression, bad treatment, ridicule, or contemptuous flouting of rules.

Yet insofar as resentment, like other reactive attitudes, can be read as a message or signal, resentment's anger, even if fearful, is not unwisely addressed to others who are not the offender but who might be in some position to reaffirm standards and so ratify the resenter's judgment, to act in defense of the victim in the form of intervention or reprisal; or to protect the victim (and perhaps others, including themselves) from repetitions of the injury. These are the responses that create or recreate the basis for confidence, trust, or hope that the boundaries that include and protect us are as we believe and need them to be. Seen in this way, the "aim" of resentment is, ideally, to activate protective, reassuring, or defensive responses in some individuals or community that can affirm the victim's being within the scope of that community's protective responsibilities or the resenter's being in fact competent in grasping and applying the community's normative expectations. The transgressor can reassure by "getting the message" and responding with acceptance of rebuke or with apology or amends. Allies can reassure by joining in confirming or corrective action. The sought-for "answer" to being "addressed" in the mode of resentment is "be assured, trust again" or "be assured, we judge as you do."

Commonly enough, however, resentment turns inward, festers or roils, and is not appropriately answered. So the association of resentment with the weak, with those whose vulnerability is confirmed by the fact of their exposure to harm, exploitation, demotions, and slights, is understandable. The weak will be in harm's way precisely because their weakness invites predation or indifference. Worse, they look forward to living with injuries and slights and with the second-order fear of having always to be angry and afraid. A weak position-socially, whether structural or situational-portends that one's resentment is less likely to be "heard," or if heard to be answered. Alternatively, it is more likely when heard to attract reprisals or ridicule for its presumption rather than protection from what prompts it. The resentment of subordinates and victims can outrage their betters and tormentors when it does not amuse them. An expression of resentment can invite 
ridicule from those in a position to disqualify the one resenting as a judge. Not everyone is in a position to brandish Butler's weapon; the likely results of doing so, at any rate, are not a constant across situations or social positions. The seductive glimmer of truth about resentment in Nietzsche's account of ressentiment is that the weak might have to be "expert in silence, in long memory, in waiting, in provisional self-depreciation, and in self-humiliation. ${ }^{28}$ Nietzsche was right to call this corrosively fearful anger "poisonous." Thwarted resentment can do damage. But it is easier to understand the nature and depth of the damage if we appreciate the degree to which resentment both expresses a sense of wrong and calls for recognition and a reparative response.

I have argued here against limiting resentment to a response to actual injury, to specifically moral injury, or to injury to oneself. Resentment functions as a reactive attitude for those who believe themselves or others injured or affronted, whether in fact they are and whether or not such injury or affront is morally objectionable. What is at stake in resentment is the mutual recognition of norms that define our society and our claims to membership in it. That is what begs to be examined when someone's resentment reveals a sense of threat. Of course, in particular cases resentment may be baseless, exaggerated, or misdirected, as other emotions can be in some instances. Even when it is, however, it serves as an extremely sensitive indicator and revealing expression of people's personal investment in what they understand to be, or what they believe should be, prevalent norms and people's investment of some social patterns with normative force. Resentment is not pleasant or attractive, but it has an important role to play in social and moral life, focusing our attention on the ongoing definition and enforcement of the standards of many types by which we live.

\section{Notes}

This essay has evolved through many presentations as part of a project on the moral psychology of responses to wrongdoing by victims, offenders, and third parties. I have presented versions at many places, and at every one I have received challenging feedback that moved me to reconsider and recast my claims. I thank audiences at the University of South Florida, State University of New York at Buffalo, Pennsylvania State University, Queens University, Dalhousie University, Syracuse University, University of Connecticut at Storrs, the Research School of Social Sciences at Australian National University and Arizona State University. Special thanks to Peggy DesAutels, Robert Richardson, and Mitchell Haney, who steered me away from a mistake about resentment and fear early on; and to Norvin Richards, whose commentary at a colloquium version of the paper at the American Philosophical Association Pacific Meeting was especially insightful and helpful.

1. Jeffrie G. Murphy and Jean Hampton, Forgiveness and Mercy (New York: Cambridge University Press, 1988).

2. Joseph Butler, Butler's Fifteen Sermons Preached at the Rolls Chapel and A Dissertation of the Nature of Virtue, ed. and with intro. and additional notes by T. A. Rob- 
erts (London: Society for Promoting Christian Knowledge, [1726] 1970), 76. A companion article, "Upon Forgiveness of Injuries," argues that this naturally designed "remedy" for deficiencies of wisdom and virtue is a painful one whose satisfaction in revenge defeats its own aim of diminishing human misery. Even so, it is only the "excess and abuse" of resentment in malice and revenge, and not the emotion itself, that is to be avoided $(81)$.

3. Ibid., 75 .

4. Ibid., 78 .

5. See Frans de Waal, Good Natured: The Origins of Right and Wrong in Human and Other Animals (Cambridge, Mass.: Harvard University Press, 1996), esp. chaps. 3 and 4 , on responses in nonhuman social primates that look very much like gratitude, indignation, and so on.

6. P. F. Strawson, "Freedom and Resentment," in The Philosophy of Thought and Action, ed. P. F. Strawson (New York: Oxford University Press, 1968).

7. Murphy and Hampton, Forgiveness and Mercy, 59-60.

8. Ibid., $55,56$.

9. Ibid., 44, 52 .

10. Ibid., 54 .

11. Ibid., 57,58 .

12. Ibid., 57 .

13. See ibid., 56 , n. 16 , for Hampton's comment that there are exceptions that nonetheless prove the rule. Another account that makes injuries to oneself the core of resentment is William E. Young, "Resentment and Impartiality," Southern Journal of Philosophy 36 (1998): 103-130.

14. See R. Jay Wallace, Responsibility and the Moral Sentiments (Cambridge, Mass.: Harvard University Press, 1996), 246-247, for a succinct discussion of why Nietzschean ressentiment is not the same as resentment. See also Claudia Card's discussion of Nietzsche in The Atrocity Paradigm (New York: Oxford University Press, 2002), chap. 2. Nietzsche's own discussion is in his On the Genealogy of Morals, trans. Francis Golffing (New York: Doubleday/Anchor Books, 1956).

15. I believe that many emotional expressions are sensitive to position in this way and that this is one of the complications of tracking the grammar of emotion concepts. One innovative and searching discussion of the issue of identifying emotions and of emotions commonly identified is in Sue Campbell, Interpreting the Personal: Expression and the Formation of Feelings (Ithaca, N.Y.: Cornell University Press, 1997).

Campbell argues that expression individuates feelings, with the important consequence that public uptake controls possibilities of expression. See also María Lugones's remarkable "Hard-to-Handle Anger," in Overcoming Racism and Sexism, ed. Linda A. Bell and David Blumenfeld (Lanham, Md.: Rowman \& Littlefield, 1995), on the communicative dimensions of anger and the difference it makes whether one expresses anger from a position of social strength or one of oppression or marginality.

16. Murphy and Hampton, Forgiveness and Mercy, 55.

17. Ibid., 16.

18. Strawson, "Freedom and Resentment," 75.

19. Unfair advantage is included in the description of resentment in Murphy and Hampton, Forgiveness and Mercy, 16.

20. Alan Gibbard points out, "Weird haircuts ... make people angry, regularly and normally," although "our anger is mistaken," in Wise Choices, Apt Feelings: A Theory 
of Normative Judgment (Cambridge, Mass.: Harvard University Press, 1990), 187. Yet it would seem, if this kind of "offense" really is "regular and normal," that there is some description under which it is not just a mistake.

21. William Ian Miller, The Anatomy of Disgust (Cambridge, Mass.: Harvard University Press, 1997), 198-199. Miller doesn't mention resentment in this passage, although a good deal of what he says about the social valence of disgust and contempt is relevant to resentment as well. Civil disattendability shades off rather too readily into norms of "respectability" that load hierarchical social arrangements, sheer prejudice, and socially sanctioned contempt for and exclusion of certain groups or their "ways" from specific social locales. See Iris M. Young, Justice and the Politics of Difference (Princeton, N.J.: Princeton University Press, 1990), 136-141, on the oppressive force of "respectability." See also Susan Wendell, The Rejected Body (New York: Routledge, 1996), on the situation of those with some kinds of disabilities who are not disattendable to the "normal."

22. Wallace, Responsibility and the Moral Sentiments, develops a somewhat similar view about resentment being a reflection of expectations in the context of developing a view of responsibility with affinities to Strawson. See esp. chap 2 and app. 1.

23. Norvin Richards pointed out to me the important possibility of disgusted resentment, where one resents what one nonetheless fully expected.

24. The interaction and synergy of emotions in context is a topic that deserves more treatment, especially as it may highlight the rather loose grammar of emotion concepts and some consequently fuzzy individuation of emotions. When does one emotion precipitate another, modulate another, or emerge as a kind of transformation of another? Contempt, for example, might come about in some instances as a transformation of resentment when being mobilized in anger becomes exhausting. One might start out resentful and then (as in the hostile, sexist work environment) become resentfully disgusted but finally become disgusted to the point where one depersonalizes and objectifies the unruly offenders. Then a kind of contemptuous revulsion might emerge that sees its objects as trivial or low, not as something to defend against and call to account so much as something to scorn or recoil from.

25. Two insightful discussions of bitterness are in Campbell, Interpreting the Personal, 167-172; and Lynne McFall, "What's Wrong with Bitterness?" in Feminist Ethics, ed. Claudia Card (Lawrence: University Press of Kansas, 1991).

26. Murphy and Hampton, Forgiveness and Mercy, 57, 74-76.

27. See Jonathan Bennett, “Accountability," in Philosophical Subjects, ed. Zak Van Straaten (New York: Oxford University Press, 1980); Gary Watson, "Responsibility and the Limits of Evil," in Responsibility, Character, and the Emotions, ed. Ferdinand Schoeman (New York: Cambridge University Press, 1987); and Barbara Houston, "In Praise of Blame," Hypatia 7 (1992): 128-147, on reactive attitudes as forms of address. The phrase seems to be Watson's.

28. Nietzsche, Genealogy of Morals, 172. 